pass, and the velocity was ten miles an hour. At sunset the sky in the western horizon had a peculiar smoky appearance, which extended nearly to the zenith in an east-south-east direction. On the 28 th, at 4 a.m., the same tidal phenomenon took place and lasted up to 7 a.m., but it was less intense, the alternate motions of the sea having only been observed four times. When day dawned on the 28 th there was a peculiar crimson colouration from east by north to south-east by east, and the sun after rising showed as if seen through the red shade of a sextant.

At the Seychelles, at 4 p.m. on August 27, the tide came rushing in at the rate of about four miles an hour, and rose two feet. In about half an hour it receded; it returned and receded.

This continued all night and all next day, but the action was quicker and the rise lower. The observations were taken in a channel about twenty-three feet wide, and walled in on both sides. The action continued all day and part of the next day (29th), but not so frequently. At $5 \mathrm{p} . \mathrm{m}$. on the 28 th the sun was clear and bright. At sunset there was a lurid glare all over the sky; at 6.30 it was much brighter, and at 6.45 it disappeared. On the $27^{\text {th }}$ the sky was slightly hazy all day. On the morning of the 29 th the sun at 7 a.m. was more like a full moon than anything else, and appeared about $70^{\circ}$ above the horizon, instead of as usual about $30^{\circ}$. At sunset on the 28 th the sun looked as it does through a fog on a frosty day in England.

At Rodrigues, about I.30 p.m. on the $27 \mathrm{th}$, the sea was all disturbed, resembling water boiling heavily in a pot, swinging the boats which were floating about in all directions. It was then low tide, and most of the boats were aground. This disturbance in the water made its appearance quite suddenly, lasted for about half an hour, and ceased as suddenly as it had commenced. At 2.30 p.m. a similar disturbance commenced again in the inner harbour, and the tide all of a sudden rose to a height of 5 feet I I inches, with a current of about ten knots an hour to the westward, floating all the boats which were aground, and tearing them from their moorings. All this happened in a very few minutes, and then the tide turned with equal force to the eastward, leaving the boats which were close inshore suddenly dry on the beach, and drag ging the Government boat (a large decked pinnace) from heavy moorings, and leaving her dry on the reef. At noon on the 29th the tide was about its usual height and appeared to be settled. The water was very muddy, and not nearly so salt as sea water usually is; it was little more than brackish. Since this singular occurrence took place the sky at north-west has had in the evenings, to as late as 7.15 p.m., a very threatening and strange appearance of a deep purplish red colour.

Tidal disturbances were also observed on the west coast of Réunion, and especially at St. Pierre, on the southwest coast. The maximum amplitude (in height) of this tide was about a metre and a half. The flow took scarcely five minutes to rise, after which the water remained about a minute at rest, and then receded with the same rapidity, to rise again a minute after.

At East London (South Africa) it was not low water on August 27 till 6.29 p.m. At 5.30 p.m. on that day the tide-gauge showed 2 feet 3 inches, and the tide was running in fast. The gauge showed 3 feet 3 inches at 5.38 ; I foot 8 inches at 5.45 ; I foot 3 inches at 5.49 ; and 2 feet 3 inches at 6 . Io. Thus, although it was a falling tide, the water suddenly rose $\mathrm{I}$ foot in 8 minutes, then fell I foot 7 inches in 7 minutes, and 5 inches in the next 4 minutes, and then rose $I$ foot in 21 minutes. The wind was moderate from east-south-east, and the barometer was 30.40 , with dull cloudy weather to south-east. It had been observed during the early part of the afternoon that the tide was oscillating very considerably, and ebbing very fast for neap tides.
On Sunday, August 26, while coming through the Straits of Banca, Capt Strachan, of the s.s. Anerley, thought he heard in the forenoon a noise like that of distant cannonading; about noon the noise was more distinct, and it soon attracted the attention of all on board; flashes of light were seen to the south-westward. In the evening an arch of light rose in a short time from the horizon to the zenith. Three aneroid barometers on board rose and fell to the extent of nearly an inch at short intervals. During a part of Monday, the 27th, there was total darkness. Showers of pumice-stone lasted till midnight. The Anerley ran back and anchored under the North Watcher Island. While afterwards passing Anjer Point, it was seen that the lighthouse had disappeared, and that great damage had been done.

Capt. Perrot, of the French brig Brani, reports that on August 26 to 27 , in $\mathrm{I}^{\circ} 39^{\prime}$ to $2^{\circ} 59^{\prime} \mathrm{S}$. and $89^{\circ} 56^{\prime}$ to $89^{\circ} 5 \mathrm{O}^{\prime}$ $E$. of P., constant peals of thunder were heard in the direction of Sumatra, but without any appearance of lightning in that direction. From midnight of the 27 th to II a.m. of the 28 th showers of "very white and very fine sand fell all over the vessel." More sand fell later on in the day and on the 29th. This sand obscured the atmosphere. On August 28 , in $8^{\circ} 20^{\prime} \mathrm{S}$., and $92^{\circ} \mathrm{O} 4^{\prime} \mathrm{E}$., "a great quantity of dust, supposed to be coral dust," fell on board of the County of Flint, and a specimen of the dust bas been kindly presented by Capt. Rowland, the master of that vessel. On September 9, in $4^{\circ} 57^{\prime} \mathrm{S}$. and $79^{\circ} 46^{\prime} \mathrm{E}$. of P., the French bark Gipsy, Capt. Martin, "encountered during the whole day a great bank of floating pumice-stone." On Sunday, August 26, in $0^{\circ} 32^{\prime}$ S., and $105^{\circ} 57^{\prime}$ E., Capt. Knight, of the brig Airlie heard, about 3 p.m., explosions, like the sound of heavy artillery, which continued at intervals till about Io p.m., the last report making the ship tremble all over. Next morning the rigging and deck were covered with fine gray sand like dust.

Mr. Meldrum remarks that there is no doubt that the tidal disturbances observed at Mauritius and elsewhere in the Indian Ocean were due to earthquakes. The origin of the seismic waves was apparently in the Straits of Sunda, and at a very considerable depth below the surface. There were earth-waves, forced sea-waves, and aërial waves. The destruction in Java was caused, apparently, by an immense wave of translation. The extraordinary sunrises and sunsets observed at Mauritius, Rodrigues, and the Seychelles, were probably due to the sun's light passing obliquely through fine volcanic dust floating in the air. It is not improbable that the disturbances of the magnets on August 27 were due to electric currents produced by the action of subterranean forces.

\section{THE LITERATURE OF THE FISHERIES EXHIBITION}

F ROM the moment of its inauguration, the present Exhibition has been the centre of a ceaseless activity, and we doubt if its streaming thousands of visitors have realised the amount of real work which bas gone on in their presence. The results of this, embodied in an extensive literature, are now before the public, and add another testimony to the faultless management of the governing body. The enormity of the fishing interest and the need of reform in certain of its branches, are obvious; and now that the press is speculating upon the "outcome" of this great enterprise, all eyes are turned upon the executive. The extent to which the Exhibition is under State control is in itself a guarantee of success, and we hail with pleasure that same system of descriptive labelling of the exhibits, and the publication of authentic treatises upon or cognate to them, so long characteristic of the adjacent National Museum. By this system the public nets a tangible result-a knowledge of that which 
is at stake-becoming thus prepared to form a rational estimate of the final issue.

Of these treatises or "Handtooks"-also introductory to the n:ore imfortant "Conference Papers" to be spoken of hereafter-twelve have been already I ublished, and it is to be regretted that they were not ready upon the opening day. Foremost among them is a powerful treatise on "The British Fish Trade," by His Excellency Spencer Walpole, whose authority in these matters no one will venture to doubt. Here at the outset, we encounter, in the deplored absence of reliable statistics, ore of the most formidable difficulties of the whole question, and the labour under which the author has collected those upon which he so ably generalises, speaks for itself. It is shown that the East Coaster, Manxman, and Cornishman are-for otvious reasons-gradually monopolising the "take," and in the discussion upon and ultimate denunciation of the "brand" question, every thoughtful reader will agree. That a legal reform is pending no one will coubt, and such stat $\epsilon$ ments as those on p. 3 regarding the registration of boats, and on pp. I7 and I 9 concerning the regulation of lights, suffice to show how the follies of this world can confound its administrative wisdom. This admirable work is a masterly analysis of the "cateh and distribution," and should be read by all who would grasp the question in hand.

Dealing with the purely legal aspect, Mr. F. Pollock produces an authoritative work on "The Fishery Laws." The freshwater fisheries are seen to be, of necessity, more protected by law than those of the sea, territorial waters excepted; and it is imfortant to note the extent to which conservators and other local authorities are $\epsilon$ mpowered. The present aspect of the question is ably summed up in the author's "conclusion" to this a concise and wellarranged work.

The educational side of the matter has not been overlooked. In the production of a valuable little work on the zoology of food-fishes, Mr. G. B. Howes has successfully solved the very difficult problem of so diluting a large store of special knowledge, as to present it in a form well adapted to the assimilation of the class of readers for which it was avowed]y written; and at the same time has contrived to invest it with an earnestness of tone and a dignity of conception which cannot fail to be productive of good to the most casual student. We cannot expect a composition of this kind to assume the accurate character of a text-book, and hence a few omissions, which more mature reflection would have remedied, constitute faults which should readily be overlooked. Altogether the author may fairly be congratulated on having scored a genuine success. Mr. W. S. Kent has done good service by bringing into one volume a synopsis of the distirctive characters of every species of British fish. His work, welcome for this reason alone, also embodies observations upon fishes in captivity, made during his career as naturalist to various existing aquaria. Many of them are interesting, but those upon the feeding of fishes must not be taken as necessarily indicative of their natural habits. The strange, guarded mode of progression of the Boar-fish, John Dory, and others described, can also be seen in the Pike in his native run. Much of the controversial matter in this book, befitting a conference pafer, would, so treated, have entailed a desirable curtailing of this, a popular wor $k$ of reference.

Man's all-prevailing imagination is wisely checked in "Sea Monsters Unmasked," in which Mr. H. Lee collects the scattered literature of this subject, and puts in a strong plea for the "cuttle theory," of which he is a well-known champion. An able defence of Pontoppidan is maintained, and one novel record set forth in this work is the dissipation of superstition-the kraken of our childhood-by a bishop-a Norwegian however, and in the eighteenth century. The two last-named manuals are illustrated, and all concerned merit congratulation upon the production of such exanples of xylographic art as cover pp. 18 and 2 I of the latter work.

The four following volumes are devoted to the more practical side of the inclustry. Mr. E. W. Holdsw orth gives an exceedingly clear and systematic account of "The Apparatus for Fishing," and by the use of wellchosen similes succeeds in making plain his descriptions of the most intricate a pparatus. The advances dependent upon the introduction of the "ketch-rigged" boats must, as here set fortb, impress the reader with the reed and value of improved apparatus. From the manner in which the various topics are treated by so comfetent an author, the reader can form some definite notion of the real practical difficulties which our fishermen encounter. These and other like matters are also fully dealt with in the two following works, by Messrs. J. G. Bertram ard W. M. Adams respectively. The former is a plea for "The Unappreciated Fisherfolk," and the latter deals with the "Fisheries and Fishermen of all Countries." Much fresh testimony to the antiquity of the industry and the remarkable community of its followers- $w$ herever they are found -is brought forward in these two volumes. Their hardworked lives are shown, as generally acknowledged, to bring in but a scanty remuneration, accompanied by ceaseless anxiety and danger : how far the former is not at times due to their inherited conservatism-tsfecially as regards the bait question-remains uncertain. The moral attributes of their lives, often untainted by "civilisation," are fully attested, and any one who has witnessed the operations incident upon, say, a Scotch herring take, will know that reform in this respect is more needed among the "gutters" and others accessory to the work than among the fishermen profer. The evidence aciduced here and elsewhere foints to a need of immediate reform in the apprenticeship question, much that is bad in it being cue to existing regulations. The sketch given of the decay of the Irish fisheries is to be deplored, but of their restoration a hope still lingers. It is certain that if our fisherfolk "know nothing whatever about fish, except the way to catch them," they know this at least thoroughly. Mr. Adams claims for Oppian the dignity of an ichthyologist, and gives Elian perhaps more than his ciue on p. 16 of his book. An incident, bearing upon the foundation of "Holland's Maritime Ascendancy" (p. 37), will not fail to interest our readers at the presert time, and we note that neither Mr. Adams' researches nor those of any one else, have yet satisfactorily cleared up the origin of trawling.

It is not reassuring to compare the state of affairs in India, as detailed in Dr. Day's Manual, according to which, matters in that land stand as much in need of reform. as at home. The author attributes the existing deplorable ccndition of the Indian fishermen largely to misrule, but more especially to the weight of the salt-tax imposed by the British ; indeed, this topic is the refrain of the whole book, and the author's own investigations go far to support the belief. As might be expected, there are some curious customs and forms of apparatus described, in use among men so interesting as these from an ethnological point of view. Some speculations on p. 37 as to the behaviour of ova in mud are at least suggestive as our knowledge stands, and it is sincerely to be regretted that we have no British representative of the air-breathing Ophiocephalidæ described on p. 31, for if so, we venture to say that reform in the matter of our freshwater-fisheries would be less slow. Dr. Day also furnishes a work on "Fish Culture," in which he gives a historical review of the different aspects of this subject, not altogether favourable to our own possessions. Bewailing the need of Governmental action, and deploring the lack of statistical evidence ufon which to generalise, the writer has either collected or furnished a mass of information which will both enlighten the public and prove of service to the practical man. The style of this book is somen hat heavy, 
and mixht be improved by a little judicious thinning. Both Dr. Day's books are illustrated -in the case of the former somewhat unintelligibly. No one intereste 1 in fishing will regret the failure of an attempt (made, we believe, by the late F. Buckland) to acclimatise the Sheatfish (Silurus).

Mr. C. E. Fryer, in his work on "Salmon Fisheries," throws some doubts upon the necessity of elaborate artificial breeding, in a weighty argument, having for its key. stone the restoration of our waters by the removal of pollution. The intricacies of the vexed question in hand are ad nirably put before the reader, and the author shows that, in some cases, existing obstacles could b a removed, or that at least con idderate action could if exercised at the right time, benefisially $m$ odify the present state of affiirs. In a comparison of the "pass" and "dam" systems, the success of Cooper's pass, on the B illi sodare River, Irelind, is adduced as a strong argu nent for the salmon-ladder. The reported death, after spıwnin $x$, of the kelts of British Co!umbia opens up a new field for inquiry; and those interested in animal in elligence, so much discu;sed in these pase;, will find here some interesting additio 1 l testi nony to the capacity of tie sulmon. The author's des ription of the diwn of life on pp. 13 and I4 might be advant tgeously improve 1.

The only remaining volume, one by Mr. J. P. Wheeldon, treats of "Angiing Cubs and Preservation Sosieties"; and in traciag the growch oc muny of these it is shown that they have done goot work, as, for example, the abolition of "snatching" and "night-lining." The opening remarks, ho vever, are not favourable to the majority of those in London, whose members unfortunately constitute more thin ninety per cent. of our Thanes an fling-community. In tracing th 2 chinges wrought in our local waters, the village poacher of old is compared with the modern steam 1tunch as a destroyer, and one more protest against the latter is lodyed by the writer, a champion in the cauje. It is important to no:e that the best regulated witers are tho se in which the management $i$ is vested in the hands of resident local bodies.

Such are thes "Handbosk;" the main porion of a series which will d ubtless form a co nplete, but none too hop sful, epitom 2 of the subject-matter. We now tura to the "Conference Papars."

To meetings at which these were re $\mathrm{d}$ and discusied were all thrown open to the public, and, what is of greater importance, there were to be found present influ entials of all grades and nation ulities from royalty down to the very fishermen and dealers whose immediate interesti were under discussion. The chair was invariably occupi d by some one of authority-in one case by a sole living "Minister of Fisheries."

Of the masterly inaugural addiess delivared by Prof. Huxley, and of the paper by H.R.H the Du'ze of Edinburgh, waish formed the subject of the first sittins, the public have already been fully infor ned, and no one who was present at either of those meetings could fail to observe that the surroundings augured at least an artive future. Concerning the address, suffice it to say that the truth of the only statement upon which dissension has been raised -by a carping minority who have entirely misunderstosd the real meaning implied-has been more fully verified at eacb subsequent sitting (we refer to the inexhaustibility of the herring-fisheries). The very fact that in the latier admirable piper an attempt has been made to estimate for the first tim: our national take of fish-6I5,000 tons per annum--io say nothing of other statistics, gathered with immense labour, $i$; in itself sufficien: to justify immediate acion, strizing as it does at the very root of the evil at present existing - at the same time for ning a good starting point for future in restization.

Beyond the formal passing of a vote of thanks, these were both dis nissed without discussion, that upon the latter biing adjourned sine die; but the subject-m itters of the twenty-six papers which follow on were all freely discussed, both the length of the paper itself and of each speaker's remurks being under control, such as favoured a thorough sifting and all-round investigation of the topic under consideration-the object being to get at facts rather than to frame schemes. The Ex'ibition itself shows the far-reaching interests of the fishing industry, but in the account waich follows wa have atten, ted to rou rhly classify the wor's done in conference.

The gravity of the important q 1estion of "supply" will be seriously increased should the ingenisus argument advanzed by Sir H. Tho nps on on pp. I4 and 15 of his "Fish as Fool" be substantiate1. This prper is of great value, embodying as it does the most recent analyses in the question, of which it must $b$ a admitted that very little is known, and dissipating certain cherished but fallacious notions, in matters dietetic. Deploring our national indifference to these, the author formulates them for all conditions ofmen, on the supposition that fish shall be eaten, giving some valuable hints for practicsl treatment. It is well known that the West $\mathrm{Hi}$ yhlander would prob.ibly rather starve than eat the eel which abounds in his waters, and which, the experienced author of this paper sho $5 \mathrm{~S}$, supplie; the very requisites of which he most stand; in need.

Of first importance among a series of paper; dealing with our home sea-fisheries is that on "The Herring Fisheries of Scotland," by Mr. Duff, M.P. Certain aspects of this question have been before the public for some time pist, but the conciusions drawn by the writer all point to the introduction of inproved apparatus and harbour acco:nmodation, and to the repeal of any restrictive legislation which may exist in this-a matter in which the current officill report sho $8 \mathrm{~s}$ that we do not $\mathrm{kn}$ ) cient of the habits of the fish them ielve; to even account for their movemants, still less to legislate upon their capture. This paper will be of great value to the practical fisherman, and furnishes a good survey of all sides of th: industry. No greater argument for improved tackle can be adduced than that of the change wrought in our herring fisheries by the substitution of $c^{\text {. }}$ tton for hemp netting. The closely allied "Mrckerel an' Pilchard Fisheries" form the subject oc a thoroughly practi sal paper by Mr. T. Cornish, himselr a worker. In the absence of statistics to prove otherwise, reform points in the same direstion a; for the herring-fisheries. Fuller information on the question and probible cause of the fluctuations in the "boat-side" price of macierel (p. Io) would be ac septable. Although the habits of the pilchard baffle us, the author show; that where the ie fi ihes do occur they are most productive, and giving some interesting statistics concerning them, he arvocates the establishment of a che ıp market for their sale. In the discussion which follows, Proc. Irown Goode gives a short but interesting account of the American mackerel-fisherie. Two s'ort papers on "Trawling" and "Line Fishing," respectively by Messri. A. W. An iell and C. M. Mundahl, embrace all the infornation upon our seafi sheries other than that given above. Our readers are dou'stless aware that a Commission is no $x$ inquiring into the disputes between the advocates of these two great system; and much of the matter contained in these papers is naturaily devoted to them. An a moun: $o^{c}$ useful statistical information is collected, and certain sub idiary questions are discussed in their baaring upon the industry, notably those connected with transport. The old belief that the beam-trawl displaced and destroyed the ova of our deep-se a fishes has been but recently shattered by Sars, but Mr. Ansell ad fuces evideace to show th it the question of shore-trawling dem ands investigation. There can be no reasonable doubt but that trawiing will be the fishing of the future; it give; constant employment for the whole year, all objections raise 1 ag iinst it are dissi- 
pated, and its advance must be sought in the application of steam power. It will be generally admitted that our existing home-difficulties are in no way due to defective apparatus.

Capt. Temple, in writing on "Seal Fisheries," adopts the wise course of holding himself responsible only for those of which he has had actual experience, leaving a hiatus, filled in during discussion by Mr. Martin and others. Devoting but little attention to the legal aspect of the industry, which we venture to say stands, with us, sorely in need of reform, the author seems more hopeful than the world at large of the chances of the chase. The body of the paper sets forth the modus operandi of the unenviable life of the sealer, whose lot entails great hardship, of ten rendered none the less buoyant for an excess of oil, nor the less happy under a "truck system." More might have been said with regard to this industry.

Turning now to other countries, we have most prominent a highly important paper on "The Fishery Industries of the United States," by Prof. Brown Goode. Some idea of its contents will be formed when we say that it fully bears out the impression made by the magnificent exhibits of that country, to study which delegates have even been sent over from other lands. The paper is a mine of useful information, and the refreshing speeches which have fallen from its author during the Conference meetings have shown how much remains untapped. The accounts given of refrigerator-cars, special oyster-trains, of the utilisation of waste, and the wellknown potting system on the economic side; of floating hatcheries, of the artificial propagation of fish (twentyseven.species), and other practical topics; and on the administrative side, of the amount of liberty allowed in matters where a more jealous State might interfere, surely point to a common moral. The history of the Menhaden fishery cannot fail to strike all readers as an example of what can be done by persevering in a "new departure," and it is important to note that the system of management and insurance of the boats composing the American fishing fleets is such as to give every impetus to the work by arousing the best interests of the men, at the same time insuring those of the capitalist. The statements advanced in both this and a paper on the Canadian fisheries, by Mr. L. Z. Joneas, are based upon deductions from a most perfect system of registration. The status of the latter country-jealous of its reputation-in fishing matters is everywhere recognised, but even it has to record the failure of attempts to artificially cure the codthe staple fish of its trade-and the writer deplores, for good reasons, the want of export traders in this the leading enterprise of its fishing population. The herring and mackerel fisheries are also dealt with, and it is reassuring to us to read that for the regulation of its lobster fisheries, of ten years' standing, Government measures are still being taken. The written account of the seal fishery conveys a good notion of its importance and a far better one of its technique than do certain sanguinary models exbibited in the Newfoundland section. The method of working a steam service on a wage system (in connection with their Great Lake fisheries) is worthy of attention.

Coming nearer home, Prof. Hubrecht, on behalf of the Dutch Government, tenders some very valuable observations upon the "Oyster Culture and Fisheries in the Netherlands." Upon the present state of our oysterbeds no comment is needed, any more than upon the fruitless efforts on the part of private individuals to establish new fisheries in our own waters. The experimental evidence-the result of observations still going onbrought forward by the author is of the highest importance; statistics favourable to artificial culture are given, the period of sexual maturation has been determined, and these and other similar facts ascertained all point to the conclusion drawn, viz. that "a close time may be of service, but that the great thing appears to be to leave a fair portion of the oysters on or around a natural bed wholly undisturbed for a series of consecutive years." This fact, discovered by chance in the Netherlands, embodies the sense of a statement made by Prof. Huxley in the matter in his opening address. It is noteworthy that the purely scientific biological and physico-chemical aspects of this question have received their full share of attention.

The main question bearing upon Mr. C. Harding's paper on "Mollusks" is that of bait. As the matter stands, action would be premature, until it can be shown that other forms of bait than those now in use are of no avail. It is well known that, on the one hand, fishermen are often compelled to stay on shore for want of bait, and on the other, it must be remembered that they are as conservative in this matter as in any which concerns them; but the fact that under like circumstances the Lofoden Islanders carry on a brisk catch by aid of the "gill-net," must not be overlooked.

(To be continued.)

\section{THE PARIS OBSERVATORY EQUATORIAL}

$T \mathrm{HE}$ accompanying illustration represents the remarkable apparatus recently set up in the Observatory of Paris, to which we have before called attention, the ingenious construction of which is due to M. Lœwy, sub-director of that establishment. Begun under the administration of M. Delaunay, interrupted during the war, thanks to a new act of munificence on the part of M. Bischoffsheim, it has now been finished.

To answer the requirements of modern astronomy equatorials are necessarily gigantic. Like the guns of modern warfare, each new apparatus is constructed on a larger scale than that of its predecessors, though it is not for purposes of destruction that they are aimed at the celestial bodies.

The advantages of the new equatorial are (I) that it measures great angular distances; (2) that it enables observations to be made with comparative ease and rapidity. Seated on a fixed chair apart from the support of the instrument, the astronomer is as if placed before his writing-table. The instrument obeys him, not he the instrument.

The new telescope is bent at right angles, one part directed in a line with the axis of the eartb, and capable of turning round itself ; the other perpendicular to it, and therefore moving in the plane of the equator. At the extremity of the latter is a mirror, and at the elbow of the telescope, in the interior, another mirror, both forming with the axis an angle of $45^{\circ}$. These mirrors are intended to reflect to each other, and finally to the observer seated with his eye at the eyepiece, the image of the star which is the object of observation.

The loss of light from successive reflections is hartly perceptible. The deformation which the images might suffer from the use of mirrors of insufficient thickness bas been guarded against. In its optical qualities, too, the new equatorial is not surpassed by any telescope in the Observatory. Two advantages have thus been securedthe power of measuring great angular distances, and that of exploring the entire heavens, the observer regulating the apparatus himself, and not needing to shift bis position.

Another benefit resulting from these happy arrange ments must also be mentioned-the abolition of the Observatory with a heavy, urgainly, and expensive dome, and the substitution of one of much smaller compass and of much simpler construction. It consists of a movable part covering the object-glass end, and of a fixed part appropriated to the observer. When prozeeding to make observations the

$$
\text { I Frum Lic Nature. }
$$

